David R. Morgan, Henry Bellmon

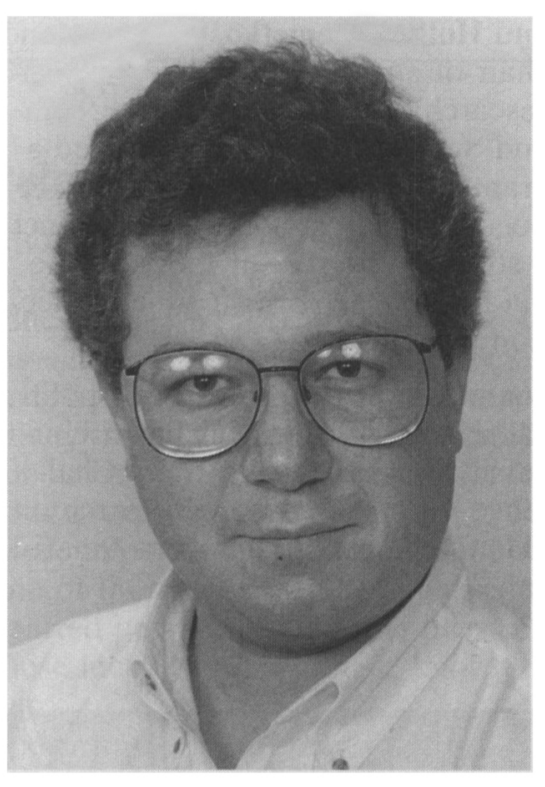

Michael Gold-Biss

Chair of Public Service, department of political Science, University of Oklahoma.

Leonard J. Schoppa, associate professor, department of government and foreign affairs, University of Virginia.

\section{Retirements}

Henry J. Abraham, professor emeritus, department of government and foreign affairs, University of Virginia.

Diane Blair, professor, department of political science, University of Arkansas.

James Hart, professor, department of government and foreign affairs, University of Virginia.

Dante Germino, professor emeritus, department of government and foreign affairs, University of Virginia.

James Sterling, professor emeritus, department of government and foreign affairs, University of Virginia.

\section{Visiting and Temporary Appointments}

Shlomo Avineri, professor of political science, Hebrew University, will be visiting professor at Cardozo School of Law in New York for the Spring 1997 term. Additionally, Avi- neri has been awarded the 1996 Israel Prize, the country's highest civilian honor.

John Dinan, visiting assistant professor, department of politics, Wake Forest University.

Margaret P. Karns, professor, political science department, University of Dayton will be visiting scholar at the University of California Center for International Studies for WinterSpring 1997, and senior associate, Pacific Council on International Policy.

\section{Awards}

\section{David R. Obey Receives 1997 Pi Sigma Alpha Award}

David R. Obey, United States Representative from Wisconsin's 7th District since 1969 has received the National Capital Area Political Science Association's 1997 Pi Sigma Alpha Award. The award, which recognizes an individual with political science training who has made a significant contribution to public affairs, was presented at the Association's Spring Conference at Mount Vernon College in Washington, DC. Congressman Obey holds two degrees from the University of Wisconsin, Madison, including an M.A. Russian government and foreign policy.

Prior to his election to Congress, Representative Obey served in the Wisconsin State Assembly where he initially was elected at the age of 24 and served seven years. In Congress, Mr. Obey has been described by the Almanac of American Politics as a "true believer in traditional liberalism, in Keynesian economics and economic redistribution ... and that government should provide economic security, create jobs and build infrastructure through public investment."

Congressman Obey served two terms as Chairman of the Joint Economic Committee and is currently a member of that committee. He also served a term as Chairman of the powerful Appropriations Committee. Today, he is the ranking minority member of the Appropriations Committee and of its Subcommittee on

\title{
Kudos . . .
}

Milda K. Hedblom, professor of politics and media, Augsburg, College, and senior associate, Hubert H. Humphrey Institute of Public Affairs, University of Minnesota, has been named the first Marks Fellow in International Communications by the Center for Strategic \& International Studies (CSIS). This new CSIS fellowship was created in honor of Ambassador Leonard Marks, recognizing his leadership in international communications and broadcasting policy.

As the first Marks Fellow, Hedblom will be engaged in diverse activities with the International Communications Studies Program of CSIS, having responsibilities for research and programs focused on policy models and regulatory issues related to information infrastructure development, particularly in the context of China's informatization programs and the European Union Information Society initiatives.

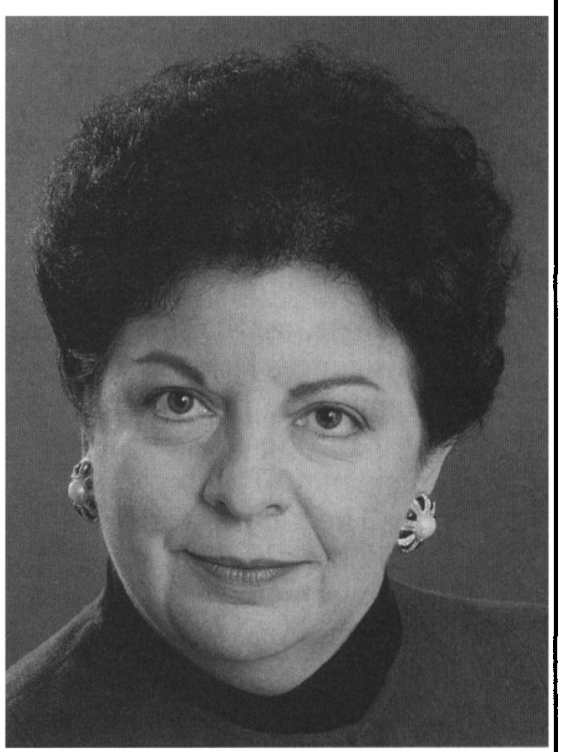

Milda K. Hedblom

Outside of academe, Hedblom has considerable experience in the public and private sectors. Her career includes she staff and program experience with the Federal Communications Commission in the Office of Plans and Policy, Office of Technology Assessment, and the Annenberg Policy Program. She is currently the Director of the Telecommunications and Information Society Forum at the Humphrey Institute and holds visiting professorships at the School of Law, Carlson School of Business and Department of Political Science, all at the University of Minnesota. She also held appointments at the University of Oslo and the University of Vienna.

Hedblom holds a B.A. with honors from Macalaster College (MN) and her M.A. and Ph.D. from the Univesity of Minnesota. She also holds a J.D. from the University of Minnesota. 


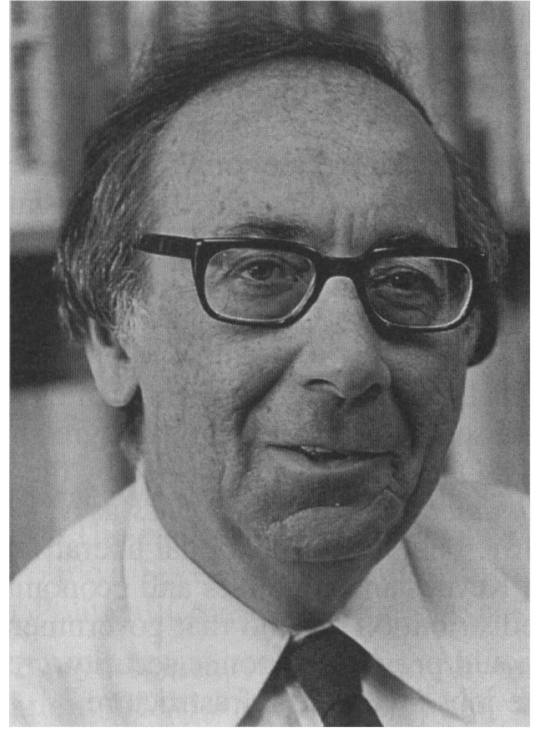

Alexander George

Labor, Health and Huaman Services and Education.

Previous NCAPSA Pi Sigman Alpha award winners are: Ernest S. Griffith, Francis O. Wilcox, Alan K. (Scotty) Campbell, Donna E. Shalala, Evron M. Kirkpatrick, Charles L. Clapp, Elmer B. Staats, Austin Ranney, Parris N. Glendening, Mark W. Cannon, Richard M. Scammon, Howard R. Penniman, Max M. Kampelman, Jeane J. Kirkpatrick, James L. Sundquist, David Price, Vincent J. Browne, William A. Galston, Stephen Horn, and Elaine C. Kamarck.

\section{Other Awards}

Meenekshi Bose, assistant professor of political science, Hofstra University, was named the first winner of the prize for the Best Dissertation on the Presidency. The prize is awarded by The Center for Presidential Studies in the George Bush School of Government and Public Service at Texas A\&M University. Bose wrote her dissertation at Princeton University under the supervision of Fred Greenstein.

William N. Cassella, former executive director of the National Municipal League, and faculty member at University of Missouri and Columbia University, was recently honored with induction into the Westchester County (NY) Senior Citizen Hall of Fame. Cassella was specially recog- nized for his lifetime of accomplishmënts. He has been a member of the Westchester County Planning Board since 1962 and its chairman since 1973.

Wolfgang Drechsler, professor and chair, department of public administration and government, University of Tartu, Estonia, has been awarded the Estonian National Science Prize for 1997 (in the social sciences, economics, and law section), the highest academic award of the country.

Alexander George, Graham H. Stuart Professor of International Relations, Emeritus, department of political science, Stanford University, was awarded the 1997 National Academy of Sciences Award for Behavioral Research Relevant to the Prevention of Nuclear War. The award is given for recognition of basic research in any field of cognitive or behavioral science that has employed rigorous formal or empirical methods, optimally a combination of these, to advance our understanding of problems related to the risk of nuclear war.

Rosemary O'Leary, associate professor of public and environmental affairs, Indiana University, was named national winner of the "Excellence in Teaching" Award given by the National Association of Schools of Public Affairs and Administration.

Hugh Perry, professor of political science, and formerly dean, School of Public Policy and Urban Affairs, Southern University-Baton Rouge, was recently appointed Chancellor's Fellow by the Southern University Board of Supervisors. The Chancellor's Fellow appointment is the highest award that can be bestowed on a faculty member at Southern UniversityBaton Rouge. It is awarded to recognize a distinguished record of teaching, research, service, and grant acquisition. Perry is the third faculty member at Southern to be appointed Chancellor's Fellow since the award was instituted by the University in Fall 1994.

Michael Rabieh, was named as the John M. Olin Fellow, HampdenSydney College. The Fellowship supports new Ph.D.s and entails half time teaching and half time research.
Margaret Scammell, lecturer, department of politics and communication studies, University of Liverpool, and Holli A. Semetko, professor and chair of audience \& public opinion research, University of Amsterdam and Syracuse University received a grant from the British Economic \& Social Research Council to conduct a study of the role of the news media in the 1997 British general election campaign.

Joanna V. Scott, professor of political science, Eastern Michigan University, has received a NEH Challenge Grant to assist in research on "Hannah Arendt Discovers American."

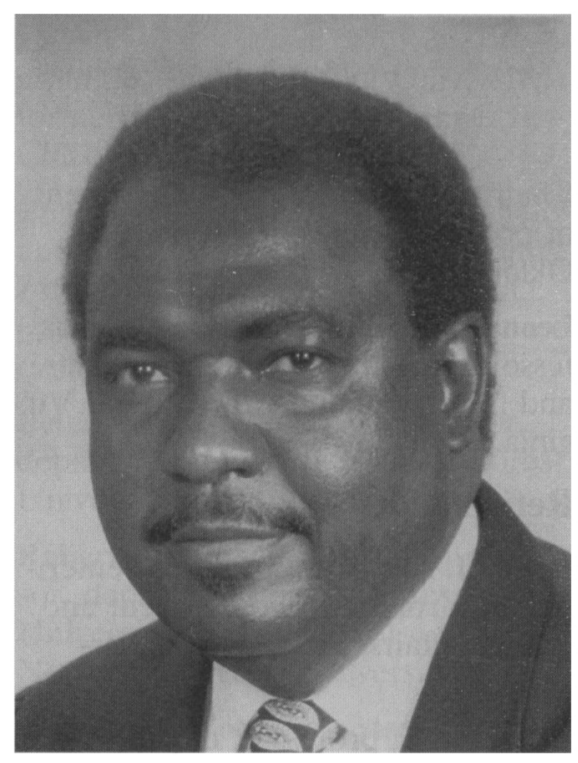

Hugh Perry

Steven T. Seitz, department of political science, Charles L. Hulin, department of psychology, University of Illinois at Urbana-Champaign and Kathy A. Hanisch, department of psychology, Iowa State University, were named winners of the 1996 Edwin E. Ghiselli Award for Research Design, conferred by the Society of Industrial and Organizational Psychology, for their paper, "Computational Modeling Applied to Organizational Withdrawal." The winning proposal discusses a computational modeling program, WORKER, developed by the authors, and its usefulness for studying employees' withdrawal processes in organizations. 